УДК 004.65.056

DOI: $10.31673 / 2412-4338.2019 .037182$

\title{
Лаптєв О.А.
}

Державний університет телекомунікацій, Київ

\section{ПОРІВНЯНИЙ АНАЛІЗ МЕТОДІВ РОЗПІЗНАВАННЯ СИГНАЛІВ РАДІОЗАКЛАДНИХ ПРИСТРОЇВ НА ОСНОВІ ЧАСТОТНИХ ПЕРЕТВОРЕНЬ}

Проведено аналіз методів перетворення сигналів. На практичних прикладах моделювання в середовищі Matlab показані переваги та недоліки перетворення Фур'є для аналізу сигналів, розглянуто швидке перетворення Фур'є в порівнянні з віконним перетворенням Фур'є, запропонована методика вибору віконних функиій при заданому розділенні та заданому динамічному діапазоні зміни сигналу. Проведено аналіз вейвлет перетворення сигналу з точки зору практичного застосування для аналізу короткочасних імпульсів сигналу.

Представлено результати моделювання прочесів перетворення сигналів в системі Matlab в розрізі порівняльного аналізу різних методів перетворення короткочасних, нестаціонарних $i$ періодично повторюваних радіосигналів. Обтрунтовано застосування вейвлет перетворення з урахуванням показника складності обчислень.

Ключові слова: перетворення Фур'є, вейвлет перетворення, радіозакладний пристрій, частотні перетворення.

\section{Laptev O.A.}

State University of Telecommunications, Kyiv

\section{COMPARATIVE ANALYSIS OF METHODS OF RECOGNITION OF SIGNALS FROM ILLEGAL RADIO EQUIPMENT BASED ON FREQUENCY TRANSFORMATIONS}

The methods of recognition of radio signals on the basis of frequency transformations of signals, such as the method of Fourier transform, the method of fast Fourier transform, window Fourier transform, the wavelet transformation, are compared. Practical examples of modeling in the Matlab environment shows the advantages and disadvantages of Fourier transform for the analysis of radio signals, considered the fast Fourier transform compared to the window Fourier transform, proposed a method for selecting window functions at a specified resolution, and specified dynamic range of signal change.

It is shown that the problem of calculating good windows is reduced to the mathematical problem of finding a time-bounded Fourier transform function that best approximates a function in frequency, i.e., they have a minimum of energy beyond a given frequency interval. It is shown that the wavelet transform method has all the advantages of the Fourier transform for recognition of radio signals. In addition, the advantage of wavelet transform over Fourier transform is that it allows to trace the change in the spectral properties of a signal over time and to indicate which frequencies (scales) dominate the signal. Considered the wavelet transform signal in terms of practical application for the analysis of short pulse signal. Presented graphic results obtained from modeling processes convert radio signals in Matlab environment in the context of a comparative analysis of different methods of signal conversion for their recognition. Attention is drawn to the pros and cons of the above methods of signal conversion in terms of the analysis of short-term, non-stationary and periodically repeated analog signals. The use of wavelet transform for the analysis of short-term signals on the amplitude-time (frequency) characteristics is justified in order to detect the operation of a digital radio-bug that works with the accumulation of information and transmits it in a short period.

Keywords: Fourier transform, wavelet transform, radio device, frequency conversion.

(C) Лаптєв О.A. 2019 
Лаптев А.А.

Государственньй университет телекоммуникаций, Киев

\section{СРАВНИТЕЛЬНЫЙ АНАЛИЗ МЕТОДОВ РАСПОЗНАВАНИЯ СИГНАЛОВ РАДИОЗАКЛАДНИХ УСТРОЙСТВ НА ОСНОВЕ ЧАСТОТНЫХ ПРЕОБРАЗОВАНИЙ}

Проведен анализ методов преобразования сигналов .. На практических примерах моделирования в среде Matlab показаны преимущества и недостатки преобразования Фурье для анализа сигналов, рассмотрены быстрое преобразование Фурье по сравнению с оконным преобразованием Фурье, предложенная методика выбора оконных функиий при заданном разрешении и заданном динамическом диапазоне изменения сигнала. Проведен анализ вейвлет преобразования сигнала с точки зрения практического применения для анализа кратковременных импульсов сигнала.

Представлены результаты моделирования прочессов преобразования сигналов в системе Matlab в разрезе сравнительного анализа различных методов преобразования кратковременных, нестационарных и периодически повторяюшихся радиосигналов. Обосновано применение вейвлет преобразования с учетом показателя сложности вычислений.

Ключевые слова: преобразования Фурье, вейвлет преобразования, радиозакладное устройство, частотные преобразования.

\section{Вступ.}

Швидкі алгоритми грають важливу роль при обробці дискретних періодичних сигналів. Найбільш популярним є швидке перетворення Фур'є (ШПФ) Класичними працями по ШПФ стали книги Макклеллана і Райдера, Блейхута, Нуссбаумера. Ключовою роботою в теорії ШПФ є робота Кулі та Тьюки. 3 того часу інтерес до ШПФ не згасає. У відомому оглядовому звіті Барраса 1997 згадується понад 3400 робіт по ШПФ. Велика частина з них - це роботи, пов'язані з обчислювальними аспектами ШПФ і питаннями реалізації ШПФ на різних ЕОМ. Питання про швидкодію стоїть дуже гостро у зв'язку з обробкою сигналів у реальному часі, а перетворення Фур'є є базовою операцією для інших алгоритмів, і швидкодія системи в цілому сильно залежить від ефективної реалізації ШПФ. Питання швидкодії в роботі автоматизованого пошукового комплексу (АПК) радіозакладок $є$ одним з визначальних, тому що процес пошуку засобів негласного отримання інформації (ЗНОI) відбувається в реальному часі.

Аналіз літературних джерел та постановка проблеми.

Аналізу перетворення аналогових сигналів присвячена велика різноманітність публікацій. Так у [1] розглядається процес перетворення стаціонарних сигналів за допомогою перетворень Фур'є. Наводиться математичний опис процесу, накладаються обмеження, відзначається його особливість і характерні області застосування. Питання застосування перетворення Фур'є для аналізу сигналів з метою виявлення радіосигналів передачі інформації не розглядається. У [2] розглядається питання перетворень Фур'є для стаціонарних і нестаціонарних сигналів. Розглядається питання обмеженості використання ШПФ для аналізу нестаціонарних сигналів, проте не розглядається варіант розв'язання пов'язаних з цим проблем. У [3] розглядається віконне перетворення сигналів, описується його переваги перед ШПФ, але не вирішується питання з методикою вибору віконної функції, відсутні практичні приклади реалізації віконного перетворення Фур'є. У [4,5] наводяться особливості вейвлет перетворення, описуються принципи його роботи, особливості різних материнських вейвлетів, наводяться варіанти збільшення роздільної здатності перетворення в застосуванні до загальних галузей науки. Конкретний вейвлет аналіз радіосигналу як набору короткочасних імпульсів сигналу не розглядається. 3 огляду на те, що процес пошуку засобів негласного отримання інформації 
відбувається в реальному часі, ефективність АПК напряму залежить від швидкого i високоякісного перетворення вхідного аналогового сигналу (радіозакладки) в цифровий вигляд, який був би зручним для аналізу програмними засобами АПК. Це зумовлює актуальність досліджень розпізнавання сигналів радіозакладних пристроїв, на основі частотних перетворень, зокрема питання розпізнавання та перетворення сигналів засобів негласного отримання інформації у цифровий вигляд з їх подальшим аналізом. Метою даною статті є аналіз існуючих методів перетворення радіосигналів та вибір метода, показники ефективності якого дозволять виявляти сигнали цифрових засобів негласного отримання інформації під час пошуку радіозакладок в режимі реального часу.

\section{Виклад основного матеріалу.}

Перетворення Фур'є стало потужним інструментом, застосовуваним в різних наукових областях, в тому числі для пошуку засобів негласного знімання інформації. У деяких випадках воно дозволяє виділяти регулярні складові в складному коливальному сигналі, завдяки чому можливо вірно інтерпретувати експериментальні спостереження в радіофізиці, акустиці, медицині та інших сферах. Аналіз Фур'є закладає основи багатьох методів, що застосовуються в області цифрової обробки сигналів (ЦОС). Перетворення Фур'є дозволяє зіставити безперервному сигналу його еквівалентне представлення в частотній області. Слід звернути увагу на те що реально існують кілька варіантів перетворень Фур'є. Головним варіантом цифрової обробки сигналів є дискретне перетворення Фур'є, яке оперує дискретною за часом вибіркою періодичного сигналу у часовій області [6].

Фундаментальне рівняння для отримання N-точкового ШПФ виглядає наступним чином:

$$
X(k)=\frac{1}{N} \sum_{n=0}^{N-1} x(n) e^{-\frac{j 2 \pi k}{N}}=\frac{1}{N} \sum_{n=0}^{N-1} x(n)\left\lceil\cos \left(\frac{2 \pi k}{N}\right)-j \sin \left(\frac{2 \pi k}{N}\right)\right\rceil
$$

де X $(\mathrm{k})$ являє собою частотний вихід ШПФ в k-ой точці спектра, k знаходиться в діапазоні від 0 до N-1, N становить число відділків при обчисленні ШПФ. Незважаючи на те, що ефективні алгоритми ШПФ існують для практично будь-яких довжин періодів, довжина, яка дорівнює ступеню двійки, залишається найпопулярнішою через максимальну продуктивність.

Основне призначення перетворення Фур'є полягає у виділенні частоти регулярних складових сигналу, в тому числі - сигналу з шумами. Завдання пошуку ЗНОІ полягає у виявлені сигналу радіозакладки, при цьому, сигнал радіозакладки маскується різними шумами.

На першому етапі розглянемо варіант виділення сигналу передбачуваної радіозакладки, якщо вона представлена звичайним періодичним сигналом, на другому етапі проаналізуємо режим їі роботи, якщо розробник спробував приховати іï методом зашумленя (для наочності в якості зашумлення розглянуто вектор, значення елементів якого є випадковими рівномірно розподіленими числами). [7]. Отримані результаті моделювання відобразимо у графічній формі засобами Matlab. На рис.1. на верхньому графіку представлений заданий періодичний сигнал, на нижньому - цей же сигнал з зашумленням. На рис. 2 відповідно представлені спектри обох сигналів, на верхньому графіку періодичного сигналу з частотами 25Гц і 50 Гц, на нижньому графіку представлений спектр цього ж сигналу з зашумленням.

Як видно $з$ рис.2,. ШПФ дозволяє виділити частоти регулярних складових сигналу 3 шумами, тобто дуже добре справляється із завданням виявлення радіозакладки (стаціонарний сигнал радіозакладки) навіть при спробі комуфліровання ії роботи випадковим шумом. Однак якщо повторити ці обчислення для нестандартного сигналу роботи радіозакладки, припустимо для сигналу з лінійною модуляцією, отримаємо результати, представлені на рис.3. Тут 
використано припущення, що зміна частоти від часу - це один з можливих варіантів роботи радіозакладки. Проводячи аналіз спектра нестандартного сигналу, представленого на рис 3, бачимо, що ШПФ не виділило реальну несучу частоту сигналу, тобто якщо до радіозакладки застосувати зашумлення нестандартним сигналом, ми не зможемо визначити їі частоту та відповідно виявити сам пристрій.

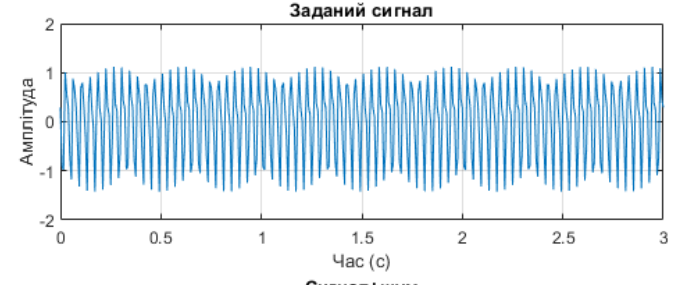

Сигнал+шум

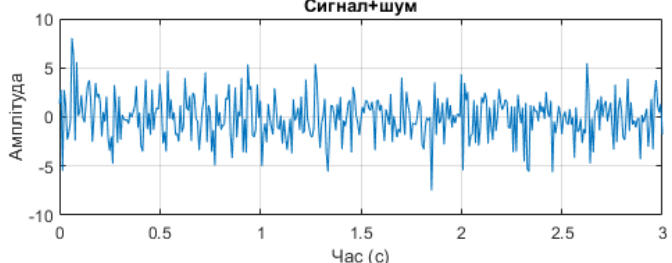

Рис.1. График заданого сигналу та цей же сигнал та зашумлення.
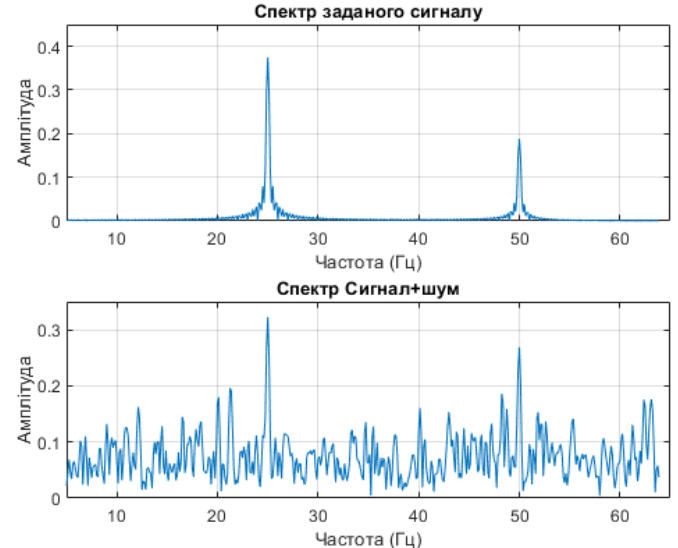

Рис.2. Спектр заданого періодичного сигналу та спектр цього ж сигналу з зашумленням.
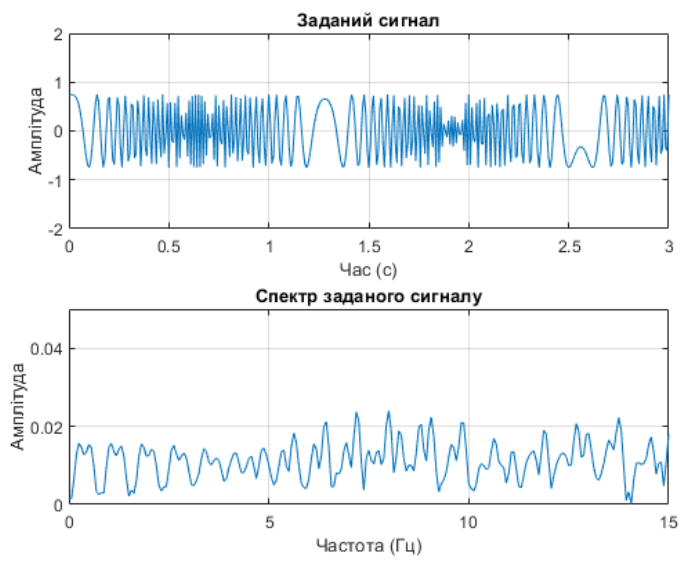

Рис.3. Графік нестандартного сигналу та його спектр отриманий ШПФ

Якщо провести спектральний аналіз стаціонарного сигналу, який складається 3 суми кількох стаціонарних сигналів з різною частотою (до прикладу двох або трьох синусоїд (косинусоїд)) (рис. 4) та аналогічний спектральний аналіз нестаціонарного сигналу, що складається 3 цих же функцій (рис.5) то отримаємо практично однаковий спектр абсолютно різних сигналів (рис. 6 та рис.7).

Звідси випливає висновок, що ШПФ показує загальні відомості про частоти досліджуваного сигналу та не дає уявлення про локальні властивості сигналу при швидких тимчасових змінах його спектрального складу. ШПФ не може аналізувати частотні характеристики сигналу в довільні моменти часу. 


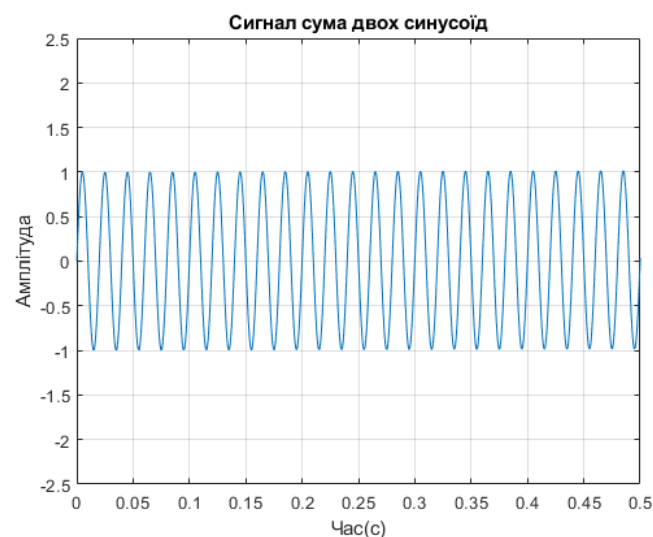

Рис.4. Заданий сигнал - сума двох синусоїд

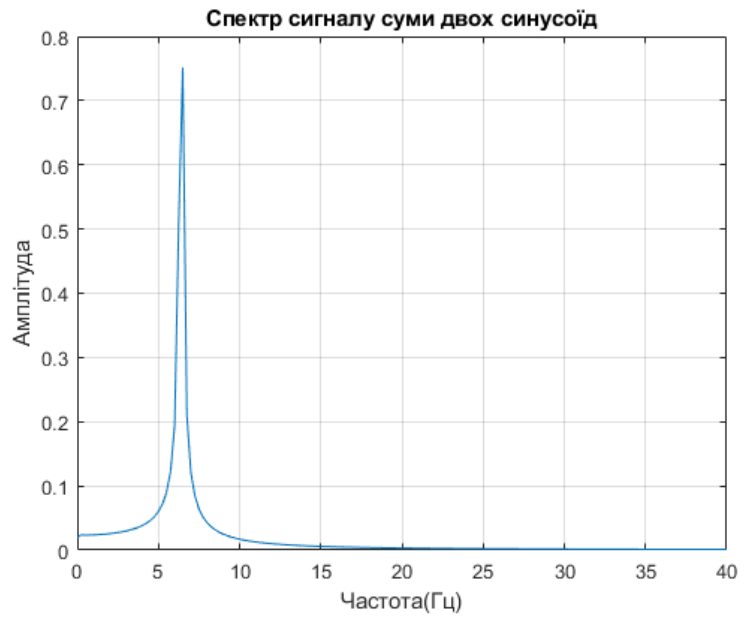

Рис.6. Спектр сигнала «сума двох синусоїд»

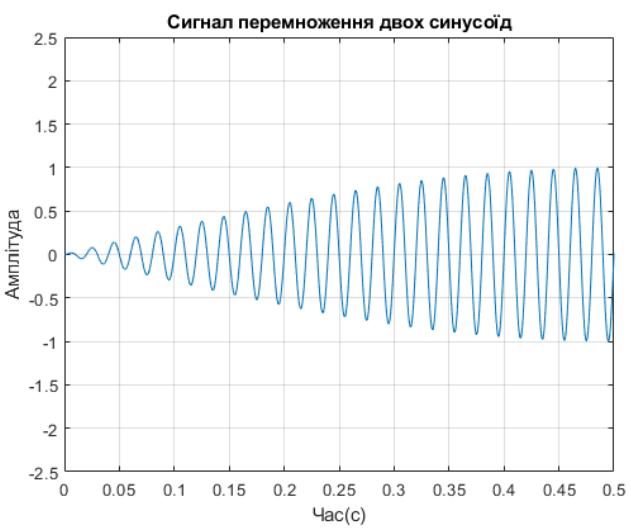

Рис.5. Заданий сигнал - перемноження двох синусоїд

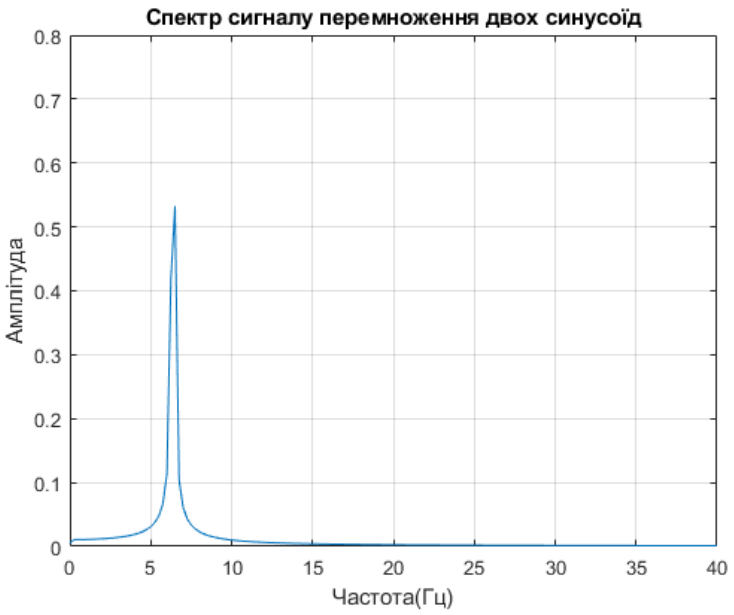

Рис.7. Спектр сигнала «перемноження двох синусоїд»

Спираючись на результати проведеного моделювання можна зробити узагальнені висновки:

1. ШПФ надає частотну інформацію, що міститься в сигналі та не дозволяє визначити момент часу виникнення і закінчення цієї частоти.

2. Спостерігається обмежена інформативність аналізу нестаціонарних сигналів і практично повна відсутність можливостей аналізу їх особливостей.

3. Гармонійні базисні функції розкладання не здатні показувати перепади сигналів 3 нескінченною крутизною, тому що для цього потрібна нескінченно велика кількість членів ряду. При обмеженні числа членів ряду Фур'є в околицях стрибків і розривів при відновленні сигналу виникає ефект Гіббса.

4. Перетворення Фур'є показує загальні відомості про частоти досліджуваного сигналу і не дає уявлення про локальні властивості сигналу при швидких тимчасових змінах його спектрального складу. Перетворення Фур'є не має можливості аналізувати частотні характеристики сигналу в довільні моменти часу.

Отримані результати свідчать, що ШПФ не підходить для аналізу радіосигналів з метою визначення сучасних радіозакладок, які працюють на принципі нестаціонарних сигналів, а також для аналізу радіоефіру, зашумленого нестаціонарними сигналами. 
3 метою усунення перерахованих вище недоліків було застосовано так зване «віконне перетворення», яке полягає в розбиття сигналу на часові ділянки. Розглянемо практичне застосування віконного перетворення. Для цього візьмемо сигнал перемножения двох синусоїд, додамо до сигналу білий шум і зробимо віконне перетворення Фур'є (рис. 8-15).

3 отриманих результатів випливає, що віконне перетворення обмежує сигнал по величині, а також зменшує амплітуду граничних значень сигналу. Зменшене амплітуди граничних значень сигналу дуже важливе при подальшому перетворенні заданого сигналу. Факт зменшення амплітуди граничних значень сигналу безпосередньо залежить від вибору віконної функції. Вибір віконної функції є одним з важливих критеріїв в цифровій обробці сигналу, тому що обмеження, які накладають на сигнал віконні функції можуть приховати необхідний сигнал радіозакладки або перешкодити його розпізнаванню.

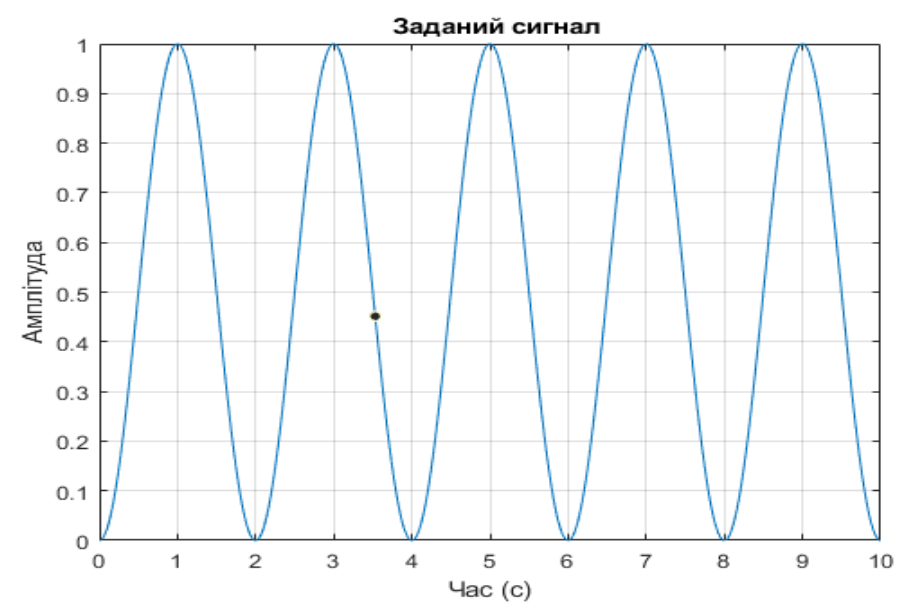

Рис. 8. Заданий сигнал перемножения двох синусоїд

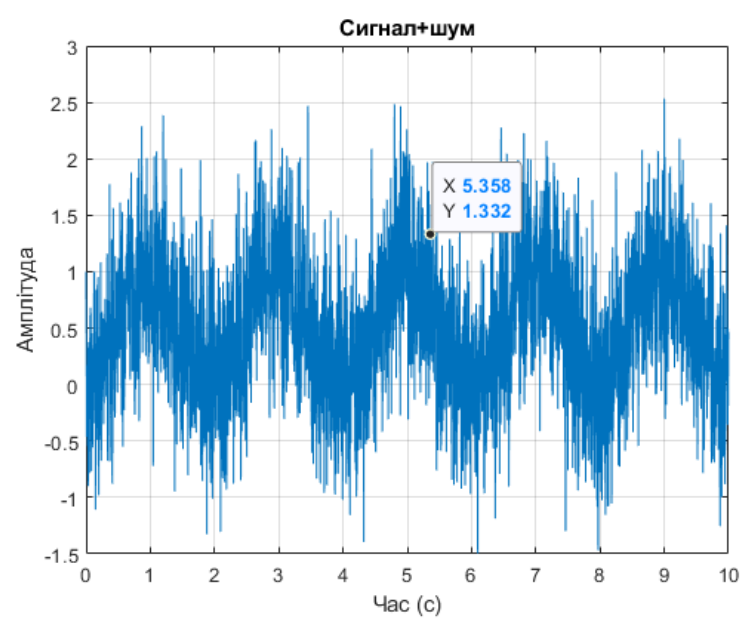

Рис.9. Заданий сигнал $з$ зашумленням

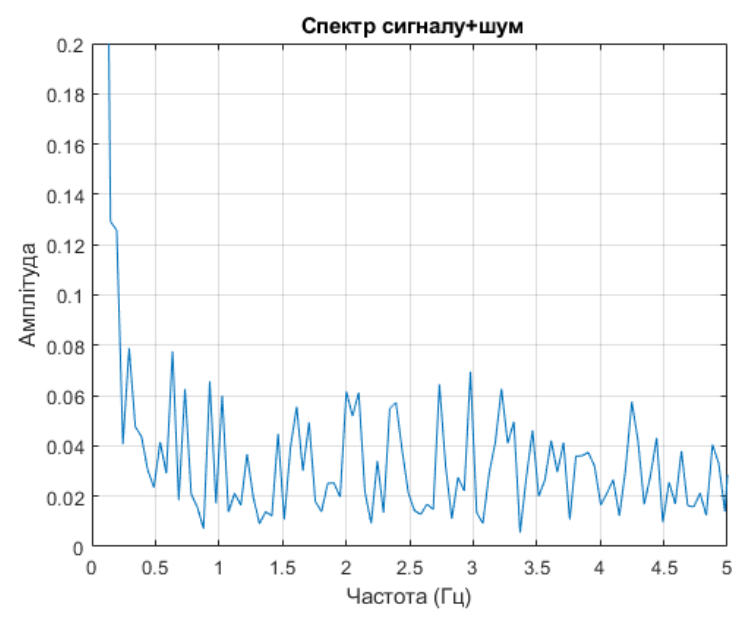

Рис.10. Спектр заданого сигналу 3 зашумленням 


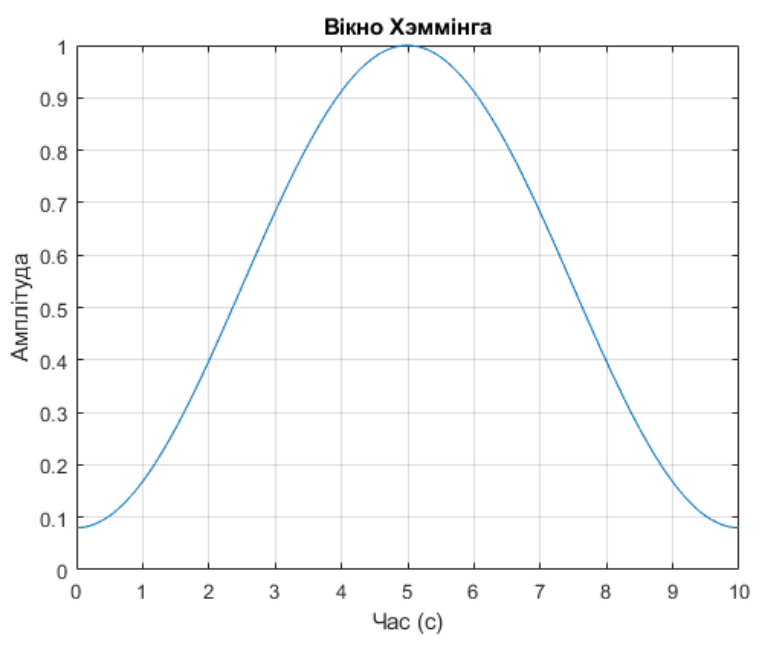

Рис.11. Вікно Хеммінга

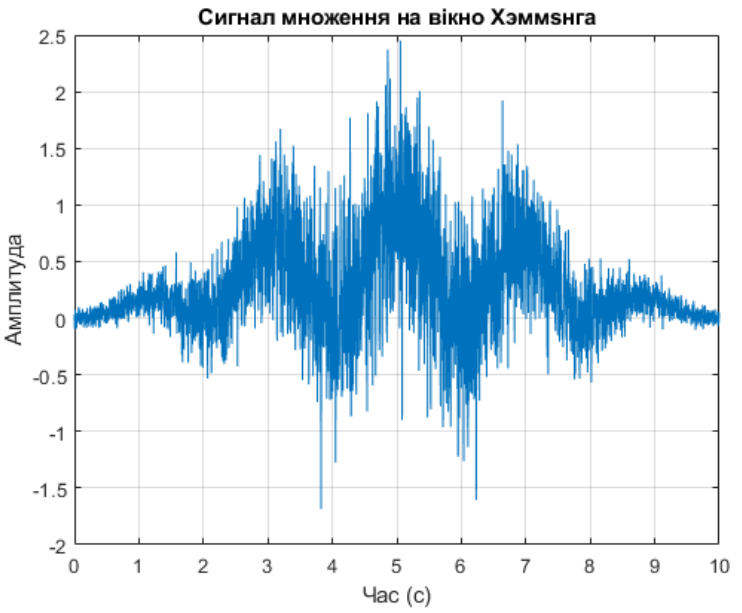

Рис.12. Перетворення заданого сигналу 3 зашумленням вікном Хеммінга

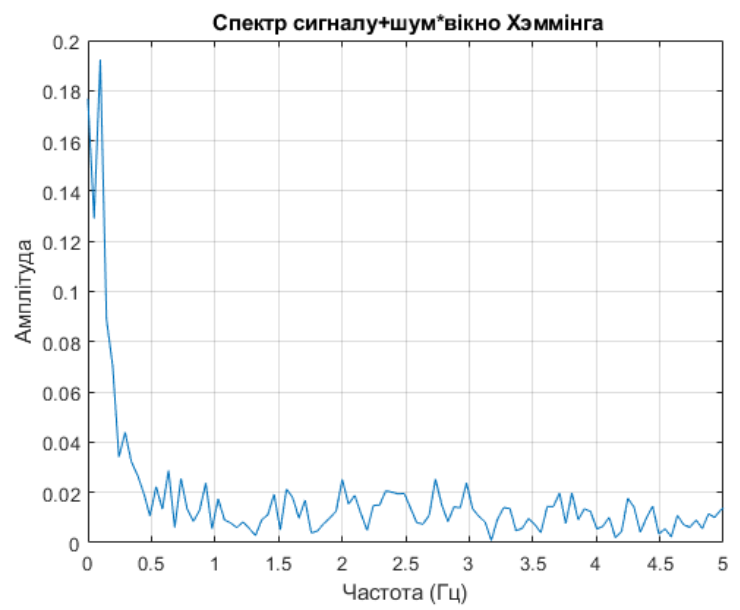

Рис. 14 Спектр заданого сигналу з зашумленям після віконного перетворення Фур'є

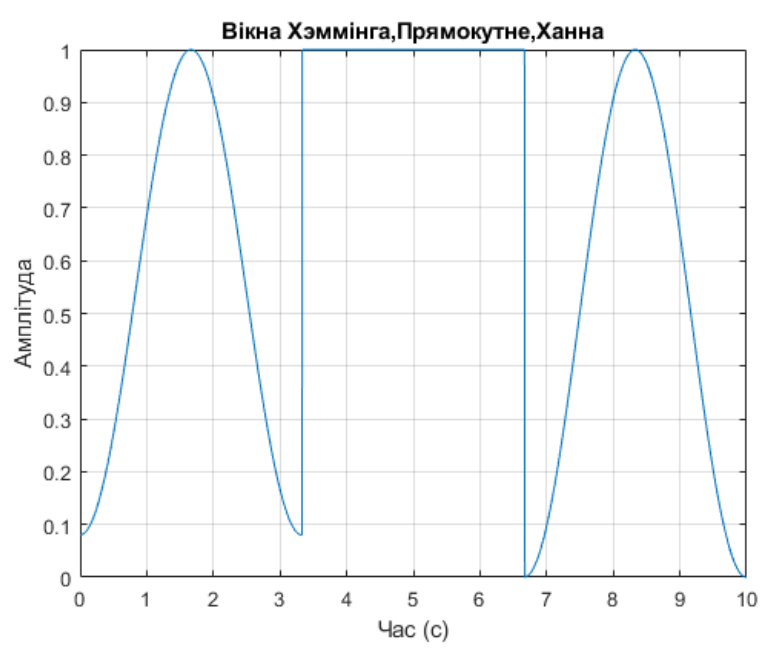

Рис.11. Вікна Хеммінга, прямокутне та Ханна

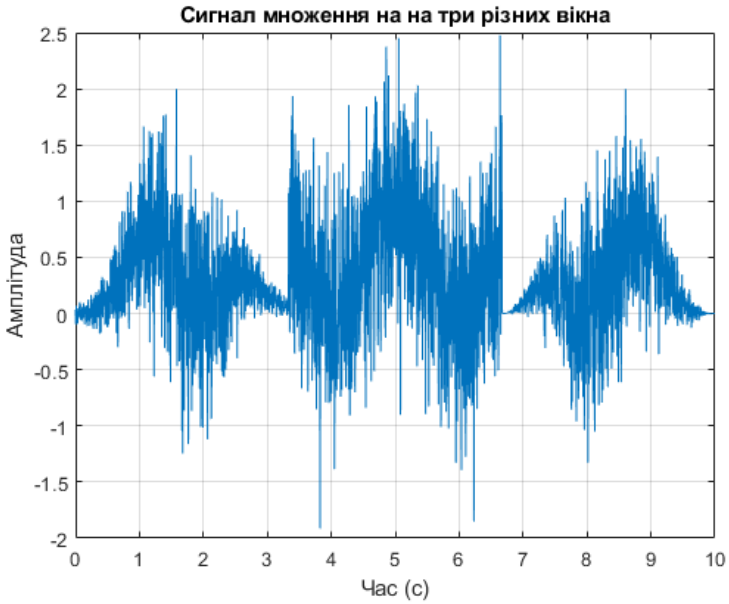

Рис.13. Перетворення заданого сигналу 3 зашумленням вікном Хеммінга, прямокутним та Ханна

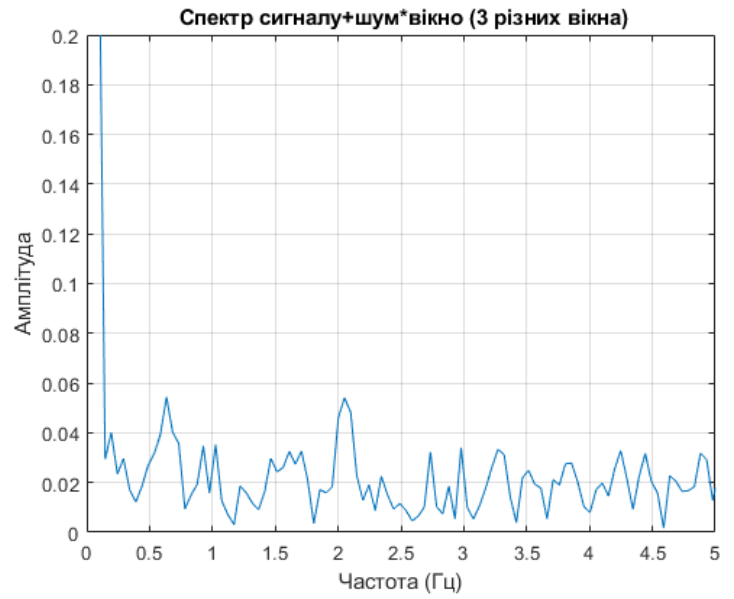

Рис.15. Спектр заданого сигналу з зашумленям після віконного перетворення Фур'є (3 різних вікна) 


\section{ISSN 2412-4338 Tелекомунікаційні та інформаційні технології. 2019. № 3 (64)}

Вибір віконної функції доцільно проводити за двома параметрами:

- динамічному діапазону сигналу;

- ширині вікна або так званому діапазону вибірки сигналу.

При пошуку радіозакладок динамічний діапазон невідомий, виходячи з чого пропонується визначати його з даних вхідного пристрою автоматизованого пошукового комплексу (АПК), яке виконує функцію аналогової цифрової обробки вхідного сигналу. Динамічний діапазон в такому випадку розраховується за формулою:

$$
D=20 \cdot \log _{10} 2^{B}=B \cdot 20 \cdot \log _{10} 2=B \cdot 6.02
$$

де $D$-динамічний діапазон в децибелах, $B$ - кількість розрядів вхідного пристрою АПК.

Для подальших розрахунків використовуються дані віконних функцій, наведені в табл.1.

Властивості деяких віконних функцій

\begin{tabular}{|l|l|l|}
\hline Найменування вікна & $\Delta F_{0}$ & $D$, дБ \\
\hline Вікно Хемминга (Hamming window) & 4 & -42 \\
\hline Вікно Блэкмана (Blackman window) & 6 & -58 \\
\hline Вікно Блэкмана — Хappиса (Blackman-Harris window) & 8 & -92 \\
\hline Вікно Наталла (Nuttall window) & 8 & -93 \\
\hline Вікно Блэкмана — Наталла (Blackman-Nuttall window) & 8 & -98 \\
\hline Вікно Flat top window & 10 & -69 \\
\hline
\end{tabular}

Розглянемо в якості прикладу вхідний 16-ти розрядний пристрій. Тоді згідно запропонованій методиці, треба вибирати таку віконну функцію, у якої рівень бічних пелюсток був би менше динамічного діапазону сигналу. Тобто при $\mathrm{D}=16$ * 6,02 =96,3 дБ, треба вибирати вікно Блекмана - Наталля. (див. табл.1). Надалі, згідно методики вибору вікна, потрібно забезпечити необхідну роздільність за частотою, для цього потрібно проводити розрахунки згідно формули (2):

$$
N>\Delta F_{0} * \frac{F_{S}}{d t}
$$

де $N$ - кількість вибірки відділків сигналу, $\Delta F_{0}$ - нормована ширина головної пелюстки АЧХ віконних функцій по нульовому рівню, вибирається для конкретної віконної функції згідно табл. $1, F s$ - частота дискретизації, $d f$ - роздільність, яка нам потрібна.

Для прикладу, задаємо роздільність $d f=2$ Цц, при частоті дискретизації $F s=2$ кГц для вікна Блекмана - Наталля (дані для вікна наведені в табл.1) отримуємо N> 8000, тобто для забезпечення необхідної або заданої роздільності необхідно забезпечити вибірку відділків сигналу понад 8000. Згідно запропонованій методиці, для 16-ти розрядного вхідного пристрою з дозволом 2Гц, потрібно вибирати вікно Блекмана - Наталля з вибіркою сигналу більш за 8000.

Аналізуючи вираз (2) бачимо, що при фіксованій частоті дискретизації для збільшення роздільної здатності необхідно збільшувати вибірку сигналу, що у свою чергу призводить до збільшення часу обробки радіосигналу.

Виходячи з вищевикладеного приходимо до висновку, що перетворення радіосигналу за допомогою віконного перетворення Фур'є (далі ОПФ), усуває недоліки перетворення ШПФ, тобто аналіз вже відбувається не у частотній, а частотно-часовій області, тому сигнал 


\section{ISSN 2412-4338 Tелекомунікаційні та інформаційні технології. 2019. № 3 (64)}

розбивається на тимчасові інтервали-вікна. Однак, основною проблемою в ОПФ залишається те, що при отриманні частотно-часової характеристики сигналу з'являється так званий принцип невизначеності Гейзенберга, який виникає для параметрів часу і частоти сигналу. В основі принципу невизначеності лежить той факт, що неможливо сказати точно, яка частота присутня в сигналі в даний момент часу (можна говорити тільки про діапазон частот) і не можливо сказати в який точно момент часу частота присутня в сигналі (можна говорити лише про період часу). При цьому, можливість виявити сигнал цифрової радіозакладки, яка передає сигнал в імпульсному режимі в короткий проміжок часу стає дуже проблематичною.

Як зазначалося вище, можливо добитися необхідної точності внаслідок збільшення роздільної здатності (звуження вікна), якщо імпульси виходу в ефір радіозакладки будуть проходити з певною періодичністю, але тільки внаслідок збільшення часу обробки сигналу. Радіозакладку, яка передає накопичену інформацію в одиничному імпульсі визначити не представляється можливим, з огляду на те, що час обробки радіосигналу може виявитися більше часу виходу радіозакладки в ефір.

Проблему невизначеності Гейзенберга вирішує так зване вейвлет-перетворення [8]. Вейвлети мають вигляд коротких хвильових пакетів з нульовим інтегральним значенням, локалізованих по осі аргументів (незалежних змінних), інваріантних до зсуву та лінійних до операції масштабування (стиснення/розтягування). За локалізацією у тимчасовому та частотному поданні вейвлети займають проміжне положення між гармонійними (синусоїдальними) функціями, локалізованими по частоті, і функцією Дірака, локалізованої в часі [9]. Теорія вейвлетів не є фундаментальною теорією, але вона дає зручний і ефективний інструмент для вирішення багатьох практичних завдань, зокрема завдання визначення коротких імпульсів передачі інформації радіозакладками.

У порівнянні з перетвореннями Фур'є, вейвлети здатні 3 більш високою точністю представляти локальні особливості сигналів. На відміну від перетворень Фур'є, вейвлетперетворення одновимірних сигналів забезпечує двовимірну розгортку, при цьому частота i координата розглядаються як незалежні змінні, що дає можливість аналізу сигналів відразу у двох просторах [10]. Одна з головних особливостей вейвлетного перетворення сигналів на різних рівнях перетворення полягає в поділі функцій наближення до сигналу на дві групи: апроксимуючу - грубу, з досить повільної тимчасовою динамікою змін, і деталізуючу - 3 локальної та швидкою динамікою змін. Це можливо як в тимчасовій, так і в частотній областях представлення сигналів вейвлетами.

Основу вейвлет перетворення становить коротка хвиля, яка проходить між сигнал та $€$ свого роду вікном деякої ширини для деякого часового проміжку. Ця коротка хвиля називається материнським вейтвлетом. Материнський вейвлет - це функція яка буде прототипом всіх вікон, що будуть створюватися на тимчасовому відрізку вейвлет перетворення. За аналогією 3 віконним перетворенням Фур'є, масштаб пов'язаний зворотною залежністю 3 шириною вейвлета (вікна), чим менше хвиля, тим більше масштаб і навпаки. Особливістю є зсув за часом, який регулює рух вейвлетів вздовж часової компоненти сигналу.

Для практичної демонстрації вище запропонованих процесів проведемо процес вейвлет перетворення нестаціонарного сигналу. Розгляд стаціонарних сигналів $є$ недоцільним, оскільки вони дуже добре перетворюються ШПФ, а ОПФ практично дозволяє визначати необхідні характеристики в деякому діапазоні часу.

У якості нестаціонарного сигналу візьмемо сигнал з лінійною частотною модуляцією від 20Гц до 100 Гц для тимчасового інтервалу від 0 до 0.25 с. У якості материнського вейвлета виступає вейвлет Морлі. На рис. 16 наведено заданий сігнал. На рис.17 наведено його 
спектральний аналіз за допомогою ШПФ. На рис.18. наведено вейвлет перетворення цього ж сигналу, у якості материнського вейвлета використовувався вейвлет Морлі.

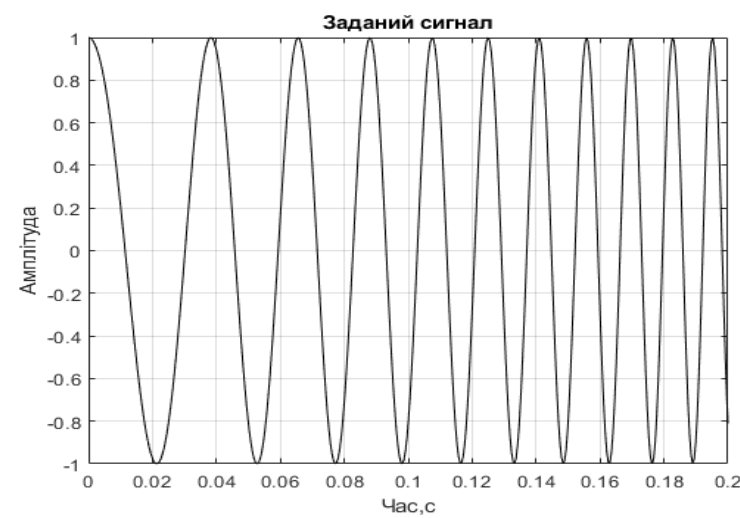

Рис.16. Заданий сигнал $з$ лінійною частотною модуляцією

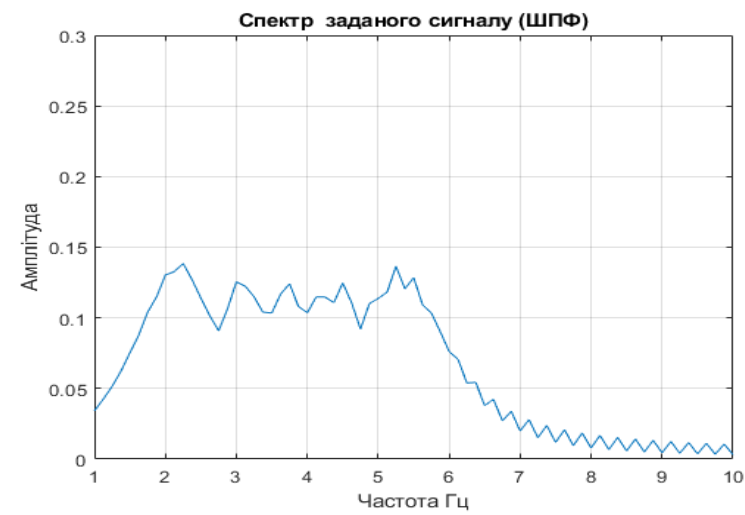

Рис.17. Перетворення ШПФ заданого сигнала

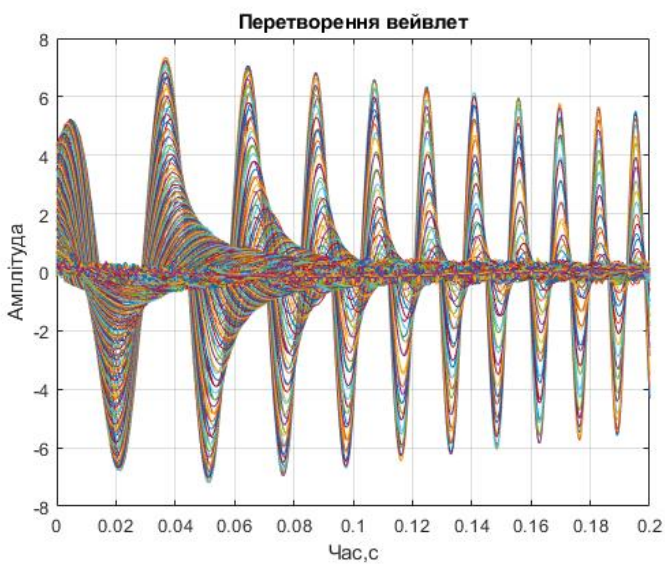

Рис.18. Вейвлет перетворення заданого сигналу (вейвлет Морлі)

3 отриманих графіків наочно видно, що вейвлет перетворення, на відміну від ШПФ, дуже точно показує характер сигналу амплітуда-час, що дозволяє зробити висновки про дуже високу ймовірність визначення імпульсної радіозакладки, яка як раз і характеризується параметрами тривалості та амплітуди імпульсу передачі інформації. Узагальнюючи аналіз отриманих графіків можна зробити висновок, що вейвлет перетворення має незаперечну перевагу при аналізі короткочасних імпульсних радіосигналів у порівнянні з іншими методами. Питання оптимізації вейвлет перетворення, які полягають у виборі материнського вейвлета та вибірці діапазону хвилі в даній статті не розглядаються.

\section{Висновки}

1. Дискретне перетворення Фур'є доречно застосовувати при перетворенні стаціонарних радіосигналів, це дозволяє в дуже короткий проміжок часу у режимі онлайн виявляти амплітуди та частоти сигналів. Якщо при цьому встановити граничні значення порога амплітуди i виконати нескладні алгоритми порівняння сигналів, отримаємо ще більш швидкодіючий процес виявлення і локалізації радіочастот (з перевищенням заданих меж).

2. Віконне перетворення Фур'є розширює можливості аналізу радіосигналів. У доповненні до всіх можливостей ШПФ аналіз проводиться в діапазонах частоти та часу, що дозволяє визначати періодично повторювані радіоімпульси, які характерні для радіозакладок 3 передачею інформації в періодичному імпульсному режимі. 


\section{ISSN 2412-4338 Tелекомунікаційні та інформаційні технології. 2019. № 3 (64)}

3. Запропоновано методику вибору віконної функції на основі динамічного діапазону сигналу та необхідної роздільності по частоті виходячи з частоти дискретизації.

4. Вейвлет перетворення, маючи всі переваги ШПФ і ОКФ, можуть при виділенні в сигналах добре локалізованих різномасштабних процесів розглядати тільки ті короткі хвилі розкладання, які представляють інтерес.

5. Практично показані переваги вейвлет перетворення перед ШПФ і ОПФ при аналізі поодиноких радіоімпульсів. Доведено, що із сучасних методів, тільки вейвлет перетворення дозволяє якісно і з високою ймовірністю визначити одиничний короткочасний сигнал, що $є$ характерним для сучасних радіозакладок.

6. Недоліком вейвлетного перетворення є складність реалізації обчислень, що уповільнює процес аналізу, однак цей недолік повністю нівелюється швидкодією сучасної обчислювальної техніки. Потужності сучасних процесорів дозволяють виконувати вейвлет перетворення в режимі реального часу.

\section{Напрямки подальших досліджень}

Подальші дослідження доцільно спрямувати на методичне обгрунтування процесу вибору материнських ветвлетів з метою оптимізації процесу перетворення аналогових нестаціонарних сигналів для їх подальшого аналізу програмними продуктами автоматизованого програмного комплексу.

\section{Список використаної літератури}

1. Рональд Н Брейсуэлл Преобразование Фурье Scientific American · Издание на русском языке № 8 август 1989. - С. 48-56 [Электронный ресурс].Режим доступа: http://www.egamath.narod.ru/Nquant/Fourier.htm (04.06.2019)

2.Практическое применение преобразования Фурье для анализа сигналов. Введение для начинающих [Электронный ресурс]. Режим доступа: https:/habr.com/ru/post/269991/ (05.07.2019)

3.Oppenheim, A. V., and R. W. Schafer, Discrete-Time Signal Processing, Prentice-Hall, 1989, pp. 447-448.

4. Анализ сигналов на основе вейвлет-преобразования. Материал из Национальной библиотеки им. Н. Э. Баумана, Последнее изменение этой страницы: 23:42, 17 ноября 2016. [Электронный ресурс].Режим доступа: https://ru.bmstu.wiki/ (11.06.2019).

5. Использование оконных функций в задачах цифрового спектрального анализа. Примеры и рекомендации [Электронный ресурс].Режим доступа: https://intellect.icu/ispolzovanie-okonnykh-funktsij-v-zadachakh-tsifrovogo-spektralnogo-analizaprimery-i-rekomendatsii-4872 (11.04.2019).

6 Спектральный анализ на ограниченном интервале времени. Оконные функции [Электронный ресурс]. Режим доступа: http://www.dsplib.ru/content/win/win.html (5.05.2019).

7. Анализ сигналов на основе вейвлет-преобразования. Материал из Национальной библиотеки им. Н. Э. Баумана, Последнее изменение этой страницы: 23:42, 17 ноября 2016. [Электронный ресурс].Режим доступа: https://ru.bmstu.wiki/ (11.06.2019).

8. Анализа сигналов для системы Matlab разработки Стэнфордского университета. [Электронный ресурс].Режим доступа: http://www.autex.spb.ru/wavelet.htm (07.06.2019)

9.Николаев В.Е., Жаркова А.И. Непрерывное вевлет преобразование в Матлаб // Молодежный научный форум: Технические и математические науки: электр. сб. ст. по мат. XXXV междунар. студ. науч.-практ. конф. № 6(35). [Электронный ресурс].Режим доступа: https://nauchforum.ru/studconf/tech/(01.05.2019). 
10. Токмолдин С.Ж.,. Клименов В.В,. Тулеуов З.Ж, Шакенов К.К. Обработка сигналов с помощью быстрого вейвлет-преобразования на суперкомпьютере в системе Матлаб [Электронный ресурс]. Режим доступа: http://repository.kaznu.kz/bitstream/handle/123456789/2057.(26.04.2019)

\section{References:}

1. Ronald N. Braiswell. "Fourier Transformation." Scientific American, Russian edition (8 August) (1989): 48-56. [Electronic resource]. Access mode: http://www.egamath.narod.ru/Nquant/Fourier.htm (04/06/2019).

2. "Practical application of the Fourier transform for signal analysis. Introduction for beginners." [Electronic resource]. Access Mode: https://habr.com/post/269991/ (07/07/2019)

3.Oppenheim, A. V., and R. W. Schafer, Discrete-Time Signal Processing, Prentice-Hall, 1989, pp. 447-448.

4. Wavelet-based signal analysis. Material from the National Library. N.E. Bauman, 17 November 2016. [Electronic resource]. Access mode: https://ru.bmstu.wiki/ (11.06.2019).

5. Use of window functions in problems of digital spectral analysis. Examples and Recommendations [Electronic resource]. Access mode: https://intellect.icu/ispolzovanie-okonnykhfunktsij-v-zadachakh-tsifrovogo-spektralnogo-analiza-primery-i-rekomendatsii-4872 (04/11/2019).

6 Spectral analysis for a limited time interval. Window Functions [Electronic resource]. Access mode: http://www.dsplib.ru/content/win/win.html (05/05/2019).

7. Wavelet Transform Analysis. Material from the National Library. N.E. Bauman, 17 November 2016. [Electronic resource]. Access mode: https://ru.bmstu.wiki/ (11.06.2019).

8. Signal analysis for Stanford University's Matlab system. [Electronic resource]. Access Mode: http://www.autex.spb.ru/wavelet.htm (06/07/2019)

9.Nikolaev VE, Zharkova AI Continuous wavelet transformation in Matlab. Youth Science Forum: Technical and Mathematical Sciences: Electr. Sat. Art. on mat. XXXV international. stud. scientific-practical Conf. 6 (35). [Electronic resource]. Access Mode: https://nauchforum.ru/studconf/tech/(01.05.2019).

10. Tokmoldin S.J.,. Klimenov VV ,. Z. Tuleuov, K. Shakenov Signal processing using a fast wavelet transform on a supercomputer in Matlab [Electronic resource]. Access Mode: http://repository.kaznu.kz/bitstream/handle/123456789/2057.(26.04.2019)

\section{Aвmopu cmammi (Authors of the article)}

Лаптсв Олександр Анатолійович - к.т.н., с.н.с, доцент кафедри систем інформаційного та кібернетичного захисту (Alexander Laptev - Candidate of Technical Sciences, Senior Researcher, Associate Professor of the Department of Information and Cybersecurity Systems). Phone:+380(67) 43480 01. E-mail: alaptev64@ukr.net 